Ambiente \& Água - An Interdisciplinary Journal of Applied Science
ISSN 1980-993X - doi:10.4136/1980-993X
www.ambi-agua.net
E-mail: ambi.agua@gmail.com

\title{
Physical, chemical, and biological properties of soil under soybean cultivation and at an adjacent rainforest in Amazonia
}

\author{
doi:10.4136/ambi-agua.1696
}

Received: 03 Jul. 2015; Accepted: 13 Oct. 2015

\author{
Troy Patrick Beldini ${ }^{1}$; Raimundo Cosme de Oliveira Junior ${ }^{2 *}$; \\ Michael Meier Keller ${ }^{3}$;Plinio Batista de Camargo ${ }^{4}$; Patrick Michael Crill ${ }^{5}$; \\ Alessandra Damasceno da Silva ${ }^{6}$; Darlisson Bentes dos Santos ${ }^{6}$; \\ Daniel Rocha de Oliveira ${ }^{6}$ \\ ${ }^{1}$ Instituto de Biodiversidade e Floresta (UFOPA), Santarém, PA, Brasil \\ ${ }^{2}$ Empresa Brasileira de Pesquisa Agropecuária (EMBRAPA), Santarém, Para, Brasil \\ ${ }^{3}$ University of New Hampshire, (UNH), New Hampshire, USA \\ ${ }^{4}$ Centro de Energia Nuclear na Agricultura USP (CENA/USP), Piracicaba, SP, Brasil \\ Laboratório de Isótopos \\ ${ }^{5}$ University of Stockholm, Sweden \\ Department of Geoscience \\ ${ }^{6}$ Centro Universitário Luterano de Santarém (CEULS/ULBRA), Santarém, PA, Brasil \\ *Corresponding author: e-mail: raimundo.oliveira-junior@embrapa.br, \\ tpbeldini@yahoo.com,mmkeller@gmail.com, pcamargo@cena.usp.br, patrick.crill@geo.su.se, \\ sda.alessandra@gmail.com, engenheirodbs@hotmail.com, handvet@yahoo.com.br
}

\begin{abstract}
Land-use change in the Amazon basin has occurred at an accelerated pace during the last decade, and it is important that the effects induced by these changes on soil properties are better understood. This study investigated the chemical, physical, and biological properties of soil in a field under cultivation of soy and rice, and at an adjacent primary rain forest. Increases in soil bulk density, exchangeable cations and $\mathrm{pH}$ were observed in the soy field soil. In the primary forest, soil microbial biomass and basal respiration rates were higher, and the microbial community was metabolically more efficient. The sum of basal respiration across the $\mathrm{A}, \mathrm{AB}$ and $\mathrm{BA}$ horizons on a mass per area basis ranged from 7.31 to $10.05 \mathrm{Mg}$ $\mathrm{CO}_{2}-\mathrm{C} \mathrm{ha}^{-1} \mathrm{yr}^{-1}$, thus yielding estimates for total soil respiration between 9.6 and $15.5 \mathrm{Mg}$ $\mathrm{CO}_{2}-\mathrm{C} \mathrm{ha}{ }^{-1} \mathrm{yr}^{-1}$ across sites and seasons. These estimates are in good agreement with literature values for Amazonian ecosystems. The estimates of heterotrophic respiration made in this study help to further constrain the estimates of autotrophic soil respiration and will be useful for monitoring the effects of future land-use in Amazonian ecosystems.
\end{abstract}

Keywords: land use change, microbial metabolic quotient, seasonality.

\section{Propriedades físicas, químicas, e biológicas de solo sob cultivação de soja e em floresta adjacente na Amazônia}

\section{RESUMO}

As mudanças no uso da terra na bacia Amazônica têm ocorridas num ritmo acelerado durante a última década, e é importante que os efeitos dessas mudanças nos recursos edáficos 
sejam explicados. Este trabalho teve como objetivo investigar as propriedades físicas, químicas, e biológicas de um solo sob cultivo de soja e arroz, e um solo de floresta primária adjacente. $\mathrm{O}$ solo do campo de soja teve aumentos na densidade, cátions trocáveis, e $\mathrm{pH}$. Na floresta primária a biomassa microbiana e a respiração do solo foram maiores, e a comunidade microbiana demonstrou maior eficiência metabólica. A soma da respiração basal nos três horizontes estudados variou entre 7,31 a $10,05 \mathrm{Mg} \mathrm{CO}_{2}-\mathrm{C} \mathrm{ha}^{-1} \mathrm{ano}^{-1}$, assim dando estimativas de 9,6 a 15,5 $\mathrm{Mg} \mathrm{CO}_{2}-\mathrm{C}$ ha $^{-1}$ ano $^{-1}$ para a respiração total do solo somada para sítios e épocas de amostragem, valores que estão de acordo com dados reportados na literatura para ecossistemas amazônicos. As estimativas da respiração heterotrófica nesse estudo ajudarão a estreitar as estimativas de respiração autotrófica e serão importantes na determinação dos efeitos de futuras mudanças no uso da terra e no clima em sistemas amazônicos.

Palavras-chave: mudança no uso da terra, quociente metabólico, sazonalidade.

\section{INTRODUCTION}

During the last decade the agricultural frontier in the Amazon has progressively migrated northward away from the crescent of deforestation that arches across the south and southeastern portion of the Amazon basin (Nepstad et al. 2006; 2008). Historically, the majority of land-use change in Amazonia has been deforestation followed by cattle pasture installation. However, during recent years the expansion of large-scale industrialized agriculture has become a major land-use change (Nepstad et al., 2006). The area under intensive mechanized agriculture in the Brazilian Legal Amazon increased by $>3.6$ million ha during 2001-2004, with 87\% of this growth in the State of Mato Grosso (Morton et al., 2006).

Soybeans occupy a larger area than any other crop in Brazil, and during the last 10 years, Amazonia became the region of Brazil with the largest increase in area under soy cultivation (Costa et al., 2007). For example, the 2006 Censo Agropecuário conducted by the Brazilian Institute of Geography and Statistics (IBGE, 2006) showed that, of the regions of Brazil, the North (Amazonia) had the largest increase in area under soy cultivation: $275.5 \%$. Furthermore, there are indications that there is considerable potential for expansion of the area under soybean cultivation in the Amazon. Vera-Diaz et al. (2007), using a regression model of soybean yield that integrates the major climatic, edaphic, and economic determinants in the Amazon Basin, estimated that $20 \%$ of the Legal Amazon could yield $2 \mathrm{Mg}$.ha ${ }^{-1}$ of soybeans, a lower-threshold value believed to make soybean cultivation economically viable.

The 2006 Censo Agropecuário also demonstrated a trend of substitution of pasture areas for cultivated areas during the period 1996 - 2006, due to the progressive insertion of Brazil into the international grain production market, principally through the cultivation of soybeans. In some areas of the Amazon, direct deforestation for soybean planting occurs. For example, in the State of Mato Grosso, Morton et al. (2006) demonstrated a strong positive relationship $\left(\mathrm{R}^{2}=0.72\right)$ between area deforested for cropland and mean annual soybean price in the year of forest clearing for the period 2001 through 2004.

The area under soybean cultivation in the Legal Amazon is approximately 2 million hectares, with 1.5 million ha in the State of Mato Grosso, and the remaining area distributed in the States of Pará, Amazonas, Roraima, and Maranhão (Costa et al., 2007). The State of Pará had 533,386 ha planted in grains under mechanized agriculture in 2009, with approximately 100,000 ha in soy. In the region of western Pará (Santarém and Belterra) there were 6,000 ha of soybeans and 550 ha of corn planted in 2003, and in 2009 there were 28,150 ha of soybeans and 11,500 ha of corn (IBGE, 2010).

Questions that arise, in light of these accelerated land-use changes in the Amazon, are how do edaphic resources change due to differing land uses, and more specifically, how does 
the biological component of the soil respond? It is the microbiological constituent of the soil that is responsible for maintaining nutrient cycling in the soil-plant-atmosphere continuum, and therefore the fertility and sustainability of the system. Rodrigues et al. (2013), studying in pasture and forest in the Amazon showed a homogenization of microbial communities in response to human activities that was driven by the loss of forest soil bacteria and a net loss of diversity. Mueller et al. (2014) sampled the soil microbial and plant community composition across a chronosequence of deforestation in the Amazon and found significant effects of landuse change on fungal community composition, which was more closely correlated to plant community composition than to changes in soil properties. Secondary forests had fungal communities more similar to primary forests than to those in pastures, which suggest that the recuperation of fungal communities after pasture abandonment is dependent upon that of plant diversity. Jesus et al. (2009) showed that microbial community structure changed significantly along gradients of base saturation, $\left[\mathrm{Al}^{3+}\right]$ and $\mathrm{pH}$ in different land use types in the Amazon, and that pasture and crop soil communities were among the most diverse.

The primary objective of this study was to compare changes in soil properties between primary forest and adjacent agricultural fields through measurements of soil chemical and physical properties, and measurements of microbial biomass and activity. In addition, through analysis of the basal respiration data, this work aimed to provide an estimate of root and total soil respiration in each of the ecosystems studied. These data will be useful for refining estimates of atmospheric $\mathrm{C}$ flux from the soil. Furthermore, these data will be useful to evaluate the effects of forest conversion and land use change on soil qualities when compared with analyses of soil from nearby native rain forest.

\section{MATERIALS AND METHODS}

This study was conducted in the Tapajós National Forest (TNF) and an adjacent $(\approx 2 \mathrm{~km})$ agricultural field (soy field). The region has a mean annual temperature of $25^{\circ} \mathrm{C}$, receives approximately $2000 \mathrm{~mm}$ of rain per year with a dry season lasting from July to December, and is located on an old, nearly flat, erosional remnant plateau (Parrotta et al., 1995). Soils are deep and highly weathered with dominantly clayey texture $(>80 \%)$. The soil type at both sites is a Typic Haplustox (red-yellow Oxisol).

The TNF is a mature, closed-canopy evergreen tropical lowland forest situated $50 \mathrm{~km}$ south of the city of Santarém, Pará, and is bordered on the east by the Santarém - Cuiabá highway for over $200 \mathrm{~km}$. Much of the area along this border is deforested and used as pasture or for industrialized agricultural activities where soy, rice, beans, corn, sorghum, and other crops are cultivated on a large scale.

Sampling in the agricultural field was conducted on the farm called "Fazenda Paraiso" at $\mathrm{km} 77$ of the Santarém-Cuiabá highway. The area in which this sampling was conducted was under Brachiara brizantha pasture until November 2001, and was then placed under a rotation of upland rice and soybean during the previous 4 years. In general, the fertilization scheme used is $50 \mathrm{~kg} \mathrm{ha}^{-1}$ of a urea-based fertilizer $\left(8 \% \mathrm{~N}, 28 \% \mathrm{P}_{2} \mathrm{O} 5,16 \% \mathrm{~K}_{2} \mathrm{O}, 0.3 \% \mathrm{Zn}\right)$ and a lime application of $2 \mathrm{t} \cdot \mathrm{ha}^{-1} \cdot \mathrm{yr}^{-1}$. In November 2005, in locations separated by about 1,000 meters, two soil pits measuring 1 meter in width by 2 meters in length by 2 meters in depth were dug in order to define the horizons, and soil samples were taken based on this horizontal differentiation. Three samples from each horizon were taken for the bulk density analysis at the midpoint of each horizon (5-, 16-, 35-, 66-, 124-, and $182 \mathrm{~cm}$ ) in each soil pit, yielding a total of 36 samples using a sliding-hammer type soil core sampler with $100 \mathrm{~cm}^{3}$ cores (AMS, Inc., American Falls, ID). Samples for analysis of soil chemical properties were taken from each horizon in the two pits yielding a total of 2 samples from each horizon, or 12 samples total from these 2 pits. Additionally, soil chemical properties samples were also taken 
at 15 randomly-located points across an area of approximately $1 \mathrm{~km}^{2}$. At each of the 15 points, 4 holes were augured to a $2 \mathrm{~m}$ depth and soil from the same horizon from each of the four auger holes was bulked and thoroughly mixed, and one composite sample was taken from this bulked sample. The 90 samples from the augured holes plus the 12 samples from the two soil pits yielded a total of 102 soil samples, or 17 samples for each horizon.

Soil samples for chemical and physical properties in the TNF were taken in November 2005 by excavating two soil pits measuring $1 \mathrm{~m} \times 1 \mathrm{~m} \times 2 \mathrm{~m}$ soil pit and taking three replicate samples (samples were not bulked) yielding a total of 2 samples from each horizon, or 12 samples total from these 2 pits. Additionally, soil chemical properties samples were also taken at 10 randomly-located points across an area of approximately 1 ha. At each of the 10 points, 4 holes were augured to a $2 \mathrm{~m}$ depth and soil from the same horizon from each of the four auger holes was bulked and thoroughly mixed, and one composite sample was taken from this bulked sample. The 60 samples from the augured holes plus the 12 samples from the two soil pits yielded a total of 72 soil samples, or 12 samples for each horizon. Bulk density samples from the TNF were taken following the same scheme used in the soy field. All soil samples for characterization of chemical properties were sent to EMBRAPA soils laboratory in Belém for analysis of $\mathrm{C}$ and $\mathrm{N}$, cation exchange capacity, exchangeable phosphorus, exchangeable acidity, $\mathrm{pH}$ and texture.

Soil samples for basal respiration and microbial biomass were taken in November 2006 (dry season) and May of 2007 (wet season) at Fazenda Paraíso and TNF. Samples were taken in the entire interval of each of the $\mathrm{A}, \mathrm{AB}$, and $\mathrm{BA}$ horizons (see Table 1 for depths) at 10 points in each land-use type. At each of the 10 sampling points, 4 holes were augured and soil from the same horizon from each of the four auger holes was bulked and thoroughly mixed, and one composite sample was taken from this bulked sample.

Table 1. Soil chemical properties in the TNF and soy field.

\begin{tabular}{lllllccccc}
\hline Site & Horizon $(\mathrm{cm})$ & $\% \mathrm{C}$ & $\% \mathrm{~N}$ & $\mathrm{pH}$ & $\mathrm{P}$ & $\mathrm{K}$ & $\mathrm{Na}$ & $\mathrm{Ca}+\mathrm{Mg}$ & $\mathrm{Al}$ \\
\hline \multirow{5}{*}{ Soy field } & Ap (0-10) & $\mathbf{1 . 8 8}$ & $\mathbf{0 . 2 3}$ & $\mathbf{5 . 2}$ & $\mathbf{2 8 . 8}$ & $\mathbf{1 0 2 . 0}$ & $\mathbf{2 6 . 6}$ & $\mathbf{2 . 9}$ & $\mathbf{0 . 4}$ \\
& AB (10-22) & 1.07 & 0.18 & 4.7 & 6.9 & 55.0 & 17.1 & 1.5 & 1.0 \\
& BA (22-48) & 0.70 & 0.14 & 4.8 & 2.1 & 39.4 & 12.5 & 0.9 & 1.3 \\
& BW1 (48-85) & 0.43 & 0.11 & 4.6 & 1.1 & 19.5 & 8.8 & 0.8 & 1.3 \\
& BW2 (85-163) & 0.36 & 0.09 & 4.7 & 1.1 & 12.8 & 6.6 & 0.82 & 1.2 \\
& BW3 (163-200) & 0.22 & 0.07 & 4.7 & 1.0 & 11.5 & 6.7 & 0.87 & 1.2 \\
& A (0-8) & 1.88 & 0.26 & 3.2 & 8 & 57 & 25 & 1.0 & 3.4 \\
& AB (8-21) & 0.71 & 0.16 & 3.6 & 3 & 22 & 10 & 0.2 & 2.3 \\
TNF & BA (21-48) & 0.47 & 0.11 & 4.0 & 1 & 10 & 6 & 0.2 & 1.7 \\
& BW1 (48-76) & 0.26 & 0.07 & 3.9 & 1 & 8 & 4 & 0.2 & 1.3 \\
& BW2 (76-125) & 0.18 & 0.06 & 4.0 & 1 & 0.2 & 0.7 & 0.2 & 0.8 \\
& BW3 (125-200) & 0.11 & 0.04 & 4.3 & 1 & 6 & 4 & 0.2 & 0.7 \\
\hline
\end{tabular}

Note: $\mathrm{P}, \mathrm{K}, \mathrm{Na}=\mathrm{mg} \cdot \mathrm{dm}^{-3} ; \mathrm{Ca}+\mathrm{Mg}$ and $\mathrm{Al}=\mathrm{cmolc} \mathrm{dm}^{-3}$.

Basal respiration was measured in the laboratory following the alkali base trap technique outlined in Anderson (1982), and soil microbial biomass was measured using the chloroform fumigation-extraction protocol in Vance et al. (1987) with subsequent analysis of the extracts done using the Walkley-Black wet oxidation method. Ten samples were taken for each procedure and in each season, and the samples were stored at $4{ }^{\circ} \mathrm{C}$ and laboratory analysis of microbial biomass and basal respiration was conducted the next day. For each procedure, samples were analyzed in triplicate and a mean value was taken for each group of three replicates. Ten grams of oven-dry soil (ODS) equivalent (soils were not oven-dried) were 
used for the basal respiration technique, and samples were brought to $60 \%$ of water-holding capacity (WHC) then incubated with $10 \mathrm{~mL}$ of $1 \mathrm{M} \mathrm{NaOH}$ for three days in $1.3 \mathrm{~L}$ glass jars sealed with Teflon tape (WHC of these soils was determined through laboratory experimentation previous to the start of the extraction and analysis of samples). Jars with only alkali solution were also prepared in order to correct for any extraneous absorption of $\mathrm{CO}_{2}$ by the samples during handling and incubation. For the microbial biomass procedure, $50 \mathrm{~g}$ of ODS brought to $60 \%$ of WHC were incubated in a glass desiccator under vacuum pressure with $30 \mathrm{~mL}$ of ethanol-free $\mathrm{CHCl}_{3}$ for 24 hours. The desiccator was protected from light with a covering of heavy, black plastic, and $200 \mathrm{~mL}$ of $\mathrm{K}_{2} \mathrm{SO} 4$ was used as an extractant. Extracts were shaken for one hour at $180 \mathrm{rpm}$ on a horizontal table shaker. The microbial metabolic quotient, or $\mathrm{qCO}_{2}$ value, was calculated as the ratio of soil basal respiration to microbial biomass (Anderson and Domsch, 1993; Wardle and Ghani, 1995). All soils data are reported on a dry-weight basis.

The microbial biomass and basal respiration data were analyzed using ANOVA with site, season, and horizon as fixed effects. Scheffe's post hoc test (Sokal and Rohlf, 1981) was used to separate means, and a probability level of $\alpha=0.05$ was used for all tests. The microbial biomass and basal soil respiration data were $\log _{10}$ transformed for the ANOVA analysis to correct for slight deviations from normality. Homogeneity of variances was tested using Levene's test and the p-value of 0.10 indicated no violation of the equal variance assumption for the ANOVA test.

The asymmetric 95\% confidence intervals for the microbial biomass, basal respiration, and $\mathrm{qCO}_{2}$ data are based on the antilog of the confidence intervals (Sokal and Rohlf, 1981), yielded from statistical testing of the $\log _{10}$ transformed data.

\section{RESULTS}

Compared to the TNF, the soy field shows large differences in $\mathrm{pH}$, exchangeable cations, and $\mathrm{P}$, differences which are most likely related to liming and fertilization. The TNF soil has a higher concentration of $\mathrm{Al}$ in the upper horizons, a difference that is once again an effect of the liming that the soy field receives, which raises the $\mathrm{pH}$. The total carbon in the first two meters was 129.0 and $151.5 \mathrm{Mg} \cdot \mathrm{ha}^{-1}$ in the soy field and TNF, respectively. Total $\mathrm{N}$ in the soy field in the first two meters was $28.1 \mathrm{Mg} \cdot \mathrm{ha}^{-1}$, and $15.9 \mathrm{Mg} \cdot \mathrm{ha}^{-1}$ in the TNF. The TNF had higher $\mathrm{C}: \mathrm{N}$ in all horizons (TNF:12.5 - 8.9 and soy: 8.1 to 3.1, A and BW3 horizons, respectively).

There are striking differences in bulk density throughout the profile up to 2 meters, with the soy field soil always having a larger bulk density than the TNF at all depths, with the largest differences in the $\mathrm{A}, \mathrm{AB}$, and $\mathrm{BA}$ horizons (for example, 0.76 and $1.4 \mathrm{Mg} \cdot \mathrm{m}^{-3}, \mathrm{~A}$ horizons in TNF and soy field, respectively; Figure 1).

The microbial biomass data followed a statistically significant trend of a larger biomass in the TNF than in the soy field in all three horizons when comparing within a season. Additionally, within a site there were statistically significant larger biomass values in the wet season than in the dry for all 3 horizons (Figure 2).

Basal respiration was greater in the TNF than in the soy field only in the A horizon in the wet season, and there were no other significant differences. The mean microbial activity, which was measured as basal respiration in the soil horizons, ranged from to 2.97 to $6.85 \mu \mathrm{g}$ $\mathrm{CO}_{2}-\mathrm{C} \cdot \mathrm{g}^{-1}$.soil h${ }^{-1}$ during the sampling period, with a general trend of greater respiration in the superficial horizons in the wet season. The microbial metabolic quotient, or $\mathrm{qCO}_{2}$ value, ranged from 4.66 to $24.89 \mu \mathrm{gCO}_{2}-\mathrm{C} \cdot \mathrm{mg}^{-1} \mathrm{~h}^{-1}$ (Figure 3). The ANOVA for $\mathrm{qCO}_{2}$ was significant for site and season, but there were no differences between the TNF and the soy field within a horizon and season (a non-significant three-way interaction term). 


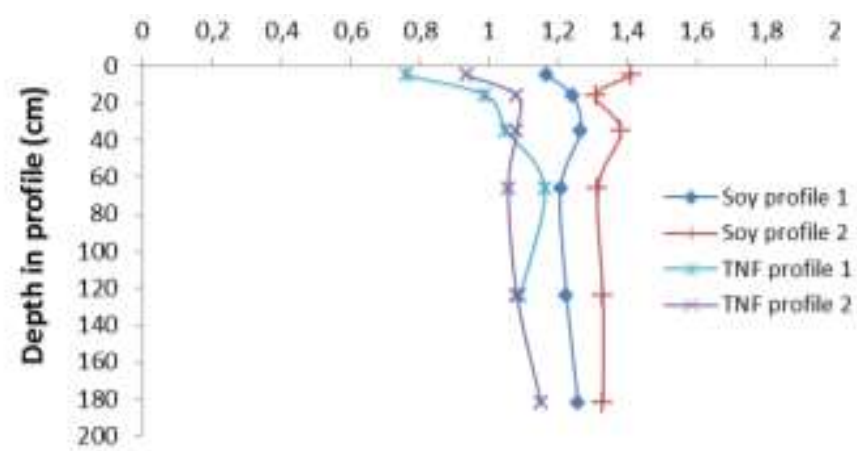

Figure 1. Soil bulk density $\left(\mathrm{Mg} \cdot \mathrm{m}^{-3}\right)$ in primary forest (TNF) and a soy field in two profiles.
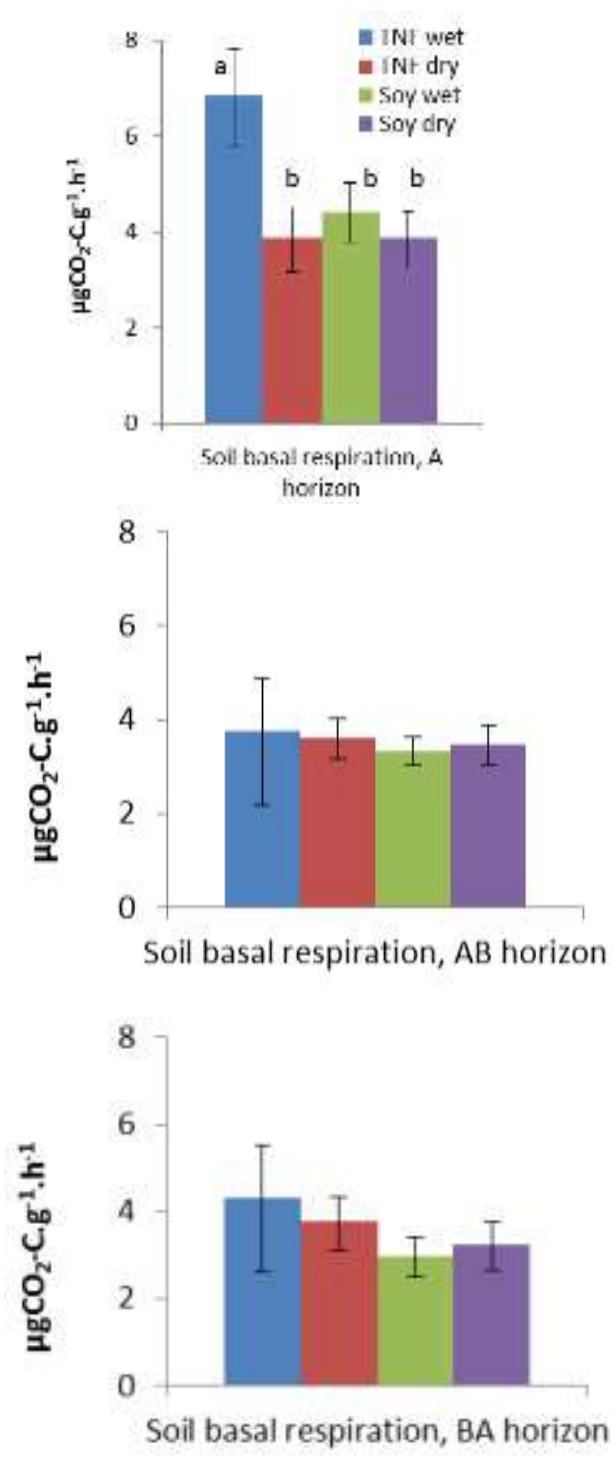
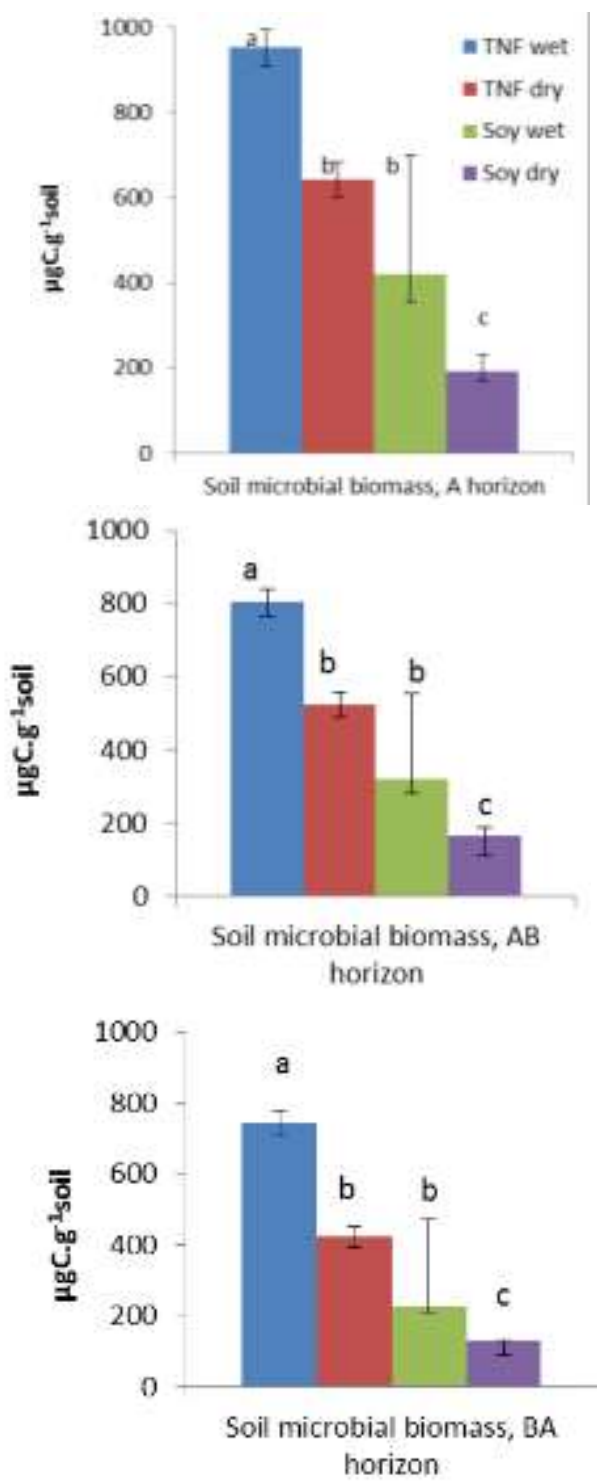

Figure 2. Soil basal respiration and microbial biomass in primary forest (TNF) and in a soy field, in 3 horizons across rainy and dry seasons. Bars are 95\% confidence intervals. Different letters indicate significant difference at $\alpha=0.05$.

Basal respiration was greater in the TNF than in the soy field only in the A horizon in the wet season, and there were no other significant differences. The mean microbial activity, which was measured as basal respiration in the soil horizons, ranged from to 2.97 to $6.85 \mu \mathrm{g}$ $\mathrm{CO}_{2}$-C.g- ${ }^{1}$.soil $\mathrm{h}^{-1}$ during the sampling period, with a general trend of greater respiration in the 
superficial horizons in the wet season. The microbial metabolic quotient, or $\mathrm{qCO}_{2}$ value, ranged from 4.66 to $24.89 \mu \mathrm{gCO}_{2}-\mathrm{C} \cdot \mathrm{mg}^{-1} \mathrm{~h}^{-1}$ (Figure 3). The ANOVA for $\mathrm{qCO}_{2}$ was significant for site and season, but there were no differences between the TNF and the soy field within a horizon and season (a non-significant three-way interaction term).
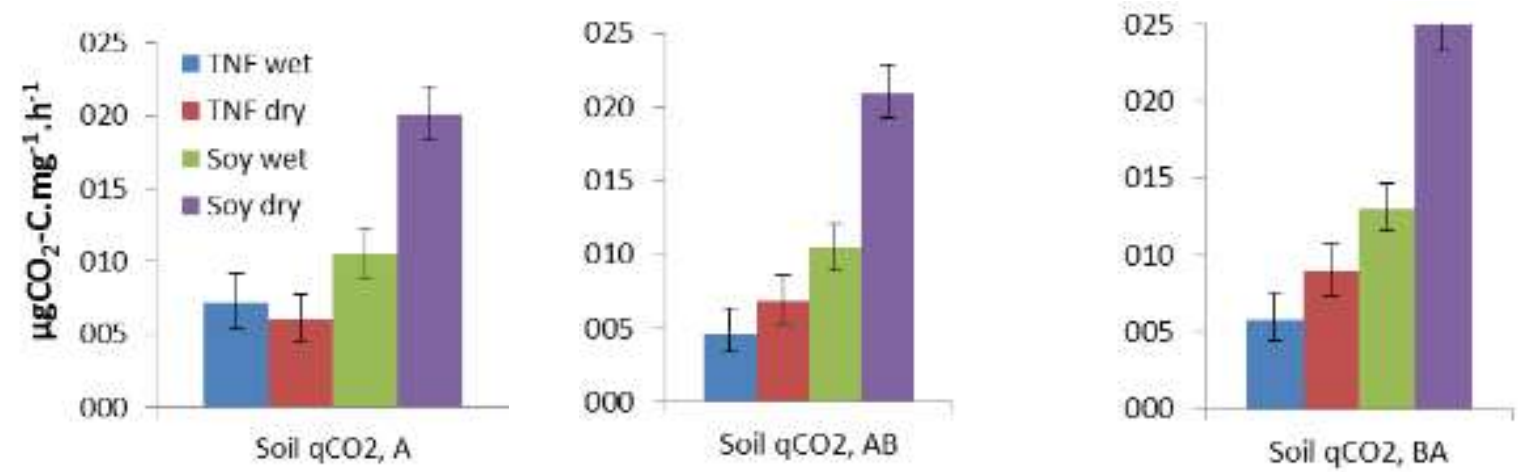

Figure 3. $\mathrm{qCO}_{2}$ values for primary forest and an agricultural field in 3 horizons across rainy and dry seasons. Bars are $95 \%$ confidence intervals.

\section{DISCUSSION}

The results for the microbial biomass analysis (Figure 2) are within the range of data reported from other studies done in Amazonian forests and other land uses. Feigl et al. (1995) reported a range of 890 to $1,100 \mu \mathrm{gC} \cdot \mathrm{g}^{-1}$, and Luizão et al. (1992) reported 765 to 1,290 $\mu \mathrm{gC} \cdot \mathrm{g}^{-1}$. Moreira and Malavolta (2004) found a range of 148 to $708 \mu \mathrm{gC} \cdot \mathrm{g}^{-1}$, in primary forest, pastures, and agroforest. Marschner et al. (2002), working in an Amazonian agroforest, found between 850 and 1,500 $\mu \mathrm{gC} \cdot \mathrm{g}^{-1}$ during the rainy season, and between 200 and $350 \mu \mathrm{gC} \cdot \mathrm{g}^{-1}$ in the dry season, and Matsuoka et al. (2003) found large decreases in soil organic matter and microbial biomass in soy fields on Oxisols in Mato Grosso. The basal soil respiration data (Figure 2) are similar to those reported in other studies done in Amazonian ecosystems. In Amazonian primary forest, Menyailo et al. (2003) reported a basal respiration rate ranging from 3.33 to $6.25 \mu \mathrm{gCO}_{2}-\mathrm{C} \cdot \mathrm{g}^{-1} \cdot \mathrm{h}^{-1}$. Likewise, Luizão et al. (1992) described basal respiration rates of 4.5 to $8.08 \mu \mathrm{gCO}_{2}-\mathrm{C} \cdot \mathrm{g}^{-1} \cdot \mathrm{h}^{-1}$ in Amazonian primary forest, burned areas, and pastures, and Feigl et al. (1995) reported a range of 5.83 to $7.25 \mu \mathrm{gCO}_{2}-\mathrm{C} \cdot \mathrm{g}^{-1} \cdot \mathrm{h}^{-}{ }^{1}$ in Amazon primary forest. The differences between the sites in the current study were not statistically significant, and a possible explanation for the equality of basal respiration between the TNF and soy field, wherein higher basal respiration rates should be expected in the TNF, might be related to the higher $\mathrm{pH}$ and lower $\mathrm{C}: \mathrm{N}$ in the soy field, factors that could stimulate microbial respiration rates. Marschner et al. (2002) reported higher $\mathrm{pH}$ values in the rhizosphere than in the bulk soil in an Amazonian forest during the wet season, and this change could promote significant changes soil $\mathrm{CO}_{2}$ efflux, microbial community composition, and substrate use and efficiency. Cenciani et al. (2009), studying microbial dynamics in Amazonian forests and pastures, concluded that elevation of $\mathrm{pH}$ in the pasture soils contributed to the greater diversity of nitrifying bacteria in comparison to forest soils. The higher $\mathrm{pH}$ and $\mathrm{N}$-fertilization of the soy field soils in the current study could have stimulated the activities of nitrifying bacteria and thus increased the basal respiration rate.

Although the differences between site, season and depth were not large, the greater respiration rate in the A horizon of the TNF soil during the wet season points to an interesting possibility to explain this result in terms of microbial community structure. For example, Cleveland et al. (2007) reported an average of $9.1 \mu \mathrm{gCO}_{2}-\mathrm{C}_{\mathrm{g}} \mathrm{g}^{-1} \cdot \mathrm{h}-{ }^{1}$ for basal respiration of lowland rain forest soils in Costa Rica. However, identical soil samples were amended with dissolved organic matter (DOM) instead of just water, and this had the effect of increasing the 
respiration rate to $35.1 \mu \mathrm{gCO} \mathrm{CO}_{2} \mathrm{C} \cdot \mathrm{g}^{-1} \cdot \mathrm{h}^{-1}$, a four-fold increase. The authors also found an increase in the abundance of organisms within the Gammaproteobacteria and Firmicutes groups, and determined that these groups are likely to have a greater ability than other organisms to respond to inputs of carbon, thus rapidly increasing the $\mathrm{CO}_{2}$ flux from the soil. This might help to explain the greater basal respiration in the TNF A horizon during the wet season (Figure 2). The dry season soils received the same treatment as the wet season soils for the basal respiration experiment, so the difference in respiration must be related to differences in the structure of the microbial communities between seasons. A possible explanation is that the A horizon of the TNF soil during the wet season may have had a different community composition that responded more efficiently to greater soil moisture. Although we have no evidence to support the following conjecture, since the soil sample was taken at a time of year when the profile would be rich in dissolved nutrients from leaching of litter fall and vegetation, this could have stimulated changes in the microbial community structure, favoring the proliferation of organisms that have a greater efficiency for substrate use, as described by Cleveland et al. (2007). The authors suggest that DOM inputs may drive higher rates of soil respiration by stimulating an opportunistic subset of the soil bacterial community, and therefore the types of microorganisms vary through time in response to different rates and types of $\mathrm{C}$ inputs, suggesting that temporal shifts in community structure may directly affect soil respiration rates following $\mathrm{C}$ inputs.

The $\mathrm{qCO}_{2}$ data in Figure 3 are similar to results published by Moreira and Costa (2004) for primary Amazon rain-forest $\left(11.8-26.1 \mu \mathrm{gCO}_{2}-\mathrm{C} \cdot \mathrm{mg}^{-1} \cdot \mathrm{h}^{-}{ }^{1}\right)$. Although there were no statistical differences, the $\mathrm{qCO}_{2}$ data support the hypothesis of changes in microbial community composition. The microbial metabolic quotient values provide an idea of the efficiency of microbial metabolic activity. Lower $\mathrm{qCO}_{2}$ values indicate that less $\mathrm{CO}_{2}$ is lost through microbial activity and more $\mathrm{C}$ is incorporated into the microbial biomass thus conferring increased efficiency of microbial activity. Lower $\mathrm{qCO}_{2}$ values are indicative of an ecosystem that is closer to steady-state condition, and higher $\mathrm{qCO}_{2}$ values are an indication of lower quality organic inputs into the soil system. Lower $\mathrm{qCO}_{2}$ values are also indicative of a larger proportion of fungal biomass since fungal metabolism is more efficient than that of bacteria. The low $\mathrm{qCO}_{2}$ in the presence of a possibly more diverse substrate input in the TNF soil during the wet season possibly indicates that subsets or groups of microbes that are more capable of metabolizing the large flush of nutrients increase in abundance. Cleveland et al. (2007) reported that specific and unique soil bacterial assemblages were responsible for the decomposition of individual soil organic compounds, and the same changes in microbial community composition could be happening in the TNF soils, and to a certain extent also in the soy field soils during the wet season.

Changes in microbial community species composition have been hypothesized to occur due to land use change and seasonal variation, and land use changes can select for specific groups of microorganisms to be dominant, or can cause decreases in microbial diversity (Cleveland et al., 2003). Marschner et al. (2002) studying soil microorganism dynamics in agro forestry systems in Amazonia concluded that during the dry season there is a less diverse microbial community, which could be due to the survival of only a subset of the population of the wet season. Cenciani et al. (2009), studying in Amazonian forest and pastures showed that, although the pasture soils had more organic $\mathrm{C}$ and $\mathrm{N}$ in the soil and the microbial biomass, mineralization of $\mathrm{C}$ and $\mathrm{N}$ during the dry season was significantly reduced compared to the forest, which may reflect a change in microbial diversity in the pasture due to seasonal variation.

The ratio of the microbial biomass $\mathrm{C}$ to total soil $\mathrm{C}$ in each horizon and season increased with depth and from dry season to rainy season for each site (TNF dry/wet 3.4/5.1; Soy dry/wet 1.0/2.3; A horizons only), a result that follows the same trend described in Luizão et al. (1992) for Amazonian forests and pasture. In the current study, the TNF always had a 
greater percentage of total $\mathrm{C}$ in the microbial biomass than did the soy field. Since the sites have nearly identical amounts of total carbon (Table 1), the difference comes from the greater amount of microbial biomass in the TNF soils, and is an indication of greater input of organic matter to the TNF soil. The large change in the ratio between seasons in the TNF, and the absence of this change in the soy field soil indicates the response of the microbial community to the large pulse of labile compounds entering the soil during the wet season, and endows the TNF soil with a greater capacity for nutrient cycling. The $\mathrm{qCO}_{2}$ data support this conclusion because the $\mathrm{qCO}_{2}$ was lower in the TNF than the soy field in all horizons, and soil carbon decreased in each successive horizon. The trend of higher $\mathrm{qCO}_{2}$ with depth, or reduced metabolic efficiency, may be an indication that soil microbial communities at these sites are C-limited. Examples of C-limitation on microbial activity in tropical soils have been shown by Cleveland and Townsend, (2006), wherein soil respiration rates were shown to be positively related to seasonal increases in labile $\mathrm{C}$ inputs in tropical forest in Costa Rica and by Ferreira et al. (2008) who demonstrated C-limitation of microbial activity in Brazilian oxisols amended with mineral $\mathrm{P}$.

The soil microbial community contribution to total soil respiration is another result from this work that provides insight into microbial activities in these systems. Soil basal respiration represents the contribution of heterotrophic organisms $(\mathrm{Rh})$ to total soil respiration (Rs). Hanson et al. (2000) in a review of root and microbial contributions to total soil respiration reported that the average contribution of $\mathrm{Rh}$ from diverse forested ecosystems worldwide was $54.2 \%$, with $45.8 \%$ coming from roots. Silver et al. (2005) investigating root dynamics and soil respiration on clay soils in the TNF reported that soil heterotrophs strongly dominate soil respiration in this forest. They concluded that fine root respiration accounts for $24-35 \%$ of total soil respiration, therefore, heterotrophic respiration would account for $65-76 \%$ of total soil respiration.

Although there is a limitation imposed when attempting to extrapolate values for Rs from the fluxes measured in the current study because they are simple laboratory incubations and are not field-measured (and also because the litter layer is not included), the range of $\mathrm{Rh}$ as a percentage of Rs would yield plausible values for total soil $\mathrm{CO}_{2}$ efflux on a $\mathrm{Mg} \mathrm{CO}_{2}-\mathrm{C} \mathrm{ha}^{-1} \mathrm{yr}^{-}$ ${ }^{1}$ basis, summed across the 3 horizons. For example, if Rh accounted for between $65-76 \%$ of $\mathrm{Rs}$, then in the TNF during the dry season, Rs would be between 9.6 and $11.3 \mathrm{Mg} \mathrm{CO} \mathrm{CO}_{2}-\mathrm{C}$ $\mathrm{ha}^{-1} \mathrm{yr}^{-1}$, and 13.0 and $15.2 \mathrm{Mg} \mathrm{CO}_{2}-\mathrm{C} \mathrm{ha}^{-1} \mathrm{yr}^{-1}$ in the wet season. Likewise, in the soy field, during the dry season, Rs would be between 12.5 and $14.7 \mathrm{Mg} \mathrm{CO}_{2}-\mathrm{C} \mathrm{ha}^{-1} \mathrm{yr}^{-1}$, and 13.2 and 15.5 $\mathrm{Mg} \mathrm{CO}_{2}-\mathrm{C} \mathrm{ha}^{-1} \mathrm{yr}^{-1}$ in the wet season. These values are in agreement with the data in Salimon et al. (2004). Working in forests and pastures in Amazonia, the authors reported a range of total annual soil $\mathrm{CO}_{2}$ flux of $13.5-27.5 \mathrm{Mg} \mathrm{CO}_{2}-\mathrm{C} \mathrm{ha}^{-1} \mathrm{yr}^{-1}$, with mean values of 24-, 17-, and $16 \mathrm{Mg} \mathrm{CO}_{2}-\mathrm{C} \mathrm{ha}^{-1} \mathrm{yr}^{-1}$ for pastures, mature forest, and secondary forest, respectively. The estimates for Rs from the current study provide an excellent fit with the estimates of Rs in Salimon et al. (2004), and therefore indicate that the estimates of Rh made in the current study are reasonably accurate. For example, the mature forest land use in Salimon et al. (2004) had a Rs range of 14.7 to $17.7 \mathrm{Mg} \mathrm{CO}_{2}-\mathrm{C} \mathrm{ha}^{-1} \mathrm{yr}^{-1}$, and the estimates for $\mathrm{Rs}\left(\mathrm{Mg} \mathrm{CO}_{2}-\mathrm{C}\right.$ $\mathrm{ha}^{-1} \mathrm{yr}^{-1}$ ) in the TNF made in the current study range from 9.6 in the dry season, to 15.2 in the wet season, with an average of 12.3. In addition, Davidson et al. (2008) working in the primary forest in the TNF reported a mean soil $\mathrm{CO}_{2}$ flux during 5 years of measurements of 12.8 $\mathrm{Mg} \mathrm{CO} 2-\mathrm{C} \mathrm{ha}^{-1} \mathrm{yr}^{-1}$. Data from soy fields in Amazonia are not well represented in the literature, but soil $\mathrm{CO}_{2}$ flux measurements from pastures have been reported. Salimon et al. (2004), calculated soil $\mathrm{CO}_{2}$ flux of $16.9 \mathrm{Mg} \mathrm{CO}_{2}-\mathrm{C} \mathrm{ha}^{-1} \mathrm{yr}^{-1}$ in a pasture that was recently (3 years) converted from a rice/bean field.

The $\mathrm{Rh}$ data from the soy field were very similar to those from the TNF (Figure 1). One explanation for the lack of large differences in $\mathrm{Rh}$ is that the $\mathrm{pH}$ in the soy field was always greater than that in the TNF (5.21 - 4.72 soy field and 3.2-4.2 TNF, A and BW3 horizons, 
respectively). The reduction in acidity induced by liming most likely stimulated microbial activity and promoted a more diverse decomposer community (Insam, 1990). The effects of liming (and fertilization) on microbial biomass can be seen in Table 2.

Table 2. Pearson product-moment correlation analysis for selected variables, soy field.

\begin{tabular}{cccccccc}
\hline Variable & $\mathrm{P}$ & $\mathrm{K}$ & $\mathrm{Na}$ & $\mathrm{Ca}$ & $\mathrm{Ca}+\mathrm{Mg}$ & $\mathrm{Al}$ & $\mathrm{pH}$ \\
\hline Microbial biomass dry season & $0.75^{*}$ & $0.72^{*}$ & $0.71^{*}$ & $0.74^{*}$ & $0.73^{*}$ & $-0.61 *$ & 0.25 \\
Microbial biomass wet season & $0.66^{*}$ & $0.42^{*}$ & $0.40^{*}$ & $0.63^{*}$ & $0.64^{*}$ & $-0.51^{*}$ & 0.26 \\
\hline
\end{tabular}

$*$ indicates significance at $\mathrm{p}<0.05$.

Correlation analysis showed only a slight positive relationship between $\mathrm{pH}$ and microbial biomass in either season, but microbial biomass was positively related to cations, and negatively related to $\mathrm{Al}$.

\section{CONCLUSIONS}

1. Compared to the nearby primary forest, soil under soy cultivation presented higher $\mathrm{pH}$, exchangeable cations, and bulk density up to 2 meters.

2. Soil microbial biomass was greater in the primary forest in both seasons, and during the wet season there were larger biomass values than in the dry for all 3 horizons comparing within and between sites.

3. The absence of differences in basal respiration between sites and seasons may be due to the application of lime and fertilizer to the soy field soil, which increased $\mathrm{pH}$ and promoted microbial activity. The soy field soils also had substantially lower $\mathrm{C}: \mathrm{N}$ in all horizons, which could also stimulate microbial respiration rates.

4. The microbial community in the forest demonstrated a tendency for higher metabolic efficiency as indicated by the $\mathrm{qCO}_{2}$ data, and the ratio of microbial carbon to soil carbon increased from dry to wet seasons. The large change in the ratio between seasons in the TNF, and the absence of this change in the soy field soil suggests a greater diversity of the microbial community in the TNF soil and therefore a greater capacity for nutrient cycling. This also suggests that the microbial community in the soy field soil may be carbon-limited.

\section{ACKNOWLEDGEMENTS}

The authors thank the TG-07 research group of the LBAECO project for funding of this work. We also thank field assistant Cleuton Pereira for his collaboration, patience and availability every day to go to the field.

\section{REFERENCES}

ANDERSON, J. P. E. Soil Respiration. In: PAGE, A. L. (Ed.). Methods of Soil analysis, Part II. Chemical and Microbiological Properties. [S.1.]: Amer Society of Agronomy, 1982. p.831-871

ANDERSON T.-H.; DOMSCH K. H. The metabolic quotient for $\mathrm{CO}_{2},(q c 02)$ as a specific activity parameter to assess the effects of environmental conditions, such as ph, on the microbial biomass of forest soils. Soil Biology and Biochemistry, 25, n. 3, p. 393-395, 1993. http://dx.doi.org/10.1016/0038-0717(93)90140-7 
CENCIANI, K.; LAMBAIS, M. R.; CERRI, C. C.; AZEVEDO, L. C. B.; FEIGL, B. J. Bacteria diversity and microbial biomass in forest, pasture and fallow soils in the southwestern Amazon basin. Revista Brasileira de Ciência do Solo, v. 33, p. 907-916, 2009. http://dx.doi.org/10.1590/S0100-06832009000400015

CLEVELAND, C. C.; TOWNSEND, A. R. Nutrient additions to a tropical rain forest drive substantial soil carbon dioxide losses to the atmosphere. Proceedings of the National Academy of Sciences, v. 103, p. 10316-10321, 2006.

http://dx.doi.org/10.1073/pnas.0600989103

CLEVELAND, C. C.; TOWNSEND A. R.; SCHMIDT, S. K.; CONSTANCE, B. C. Soil microbial dynamics and biogeochemistry in tropical forests and pastures, southwestern Costa Rica. Ecological Applications, v. 13, n. 2, p. 314-326, 2003. http://dx.doi.org/10.1890/1051-0761(2003)013[0314:SMDABI]2.0.CO;2

CLEVELAND, C. C.; NEMERGUT, D. R.; SCHMIDT, S. K.; TOWNSEND A. R. Increases in soil respiration following labile carbon additions linked to rapid shifts in soil microbial community composition. Biogeochemistry, v. 82, p. 229-240, 2007. http://dx.doi.org/10.1007/s10533-006-9065-z

COSTA, M. H.; YANAGI, S. N. M.; SOUZA, P. J. O. P.; RIBEIRO, A.; ROCHA, E. J. P. Climate change in Amazonia caused by soybean cropland expansion, as compared to caused by pastureland expansion. Geophysical Research Letters, v. 34, p. L07706, 2007. http://dx.doi.org/10.1029/2007GL029271

DAVIDSON, E. A.; NEPSTAD, D. C.; ISHIDA, F. Y.; BRANDO, P. M. Effects of an experimental drought and recovery on soil emissions of carbon dioxide, methane, nitrous oxide, and nitric oxide in a moist tropical forest. Global Change Biology, v. 14, p. 2582-2590, 2008. http://dx.doi.org/10.1111/j.1365-2486.2008.01694.x

FEIGL, B. J.; SPARLING, G. P.; ROSS, D. J.; CERRI, C. C. Soil microbial biomass in Amazonian soils: evaluation of methods and estimates of pool sizes. Soil Biology \& Biochemistry, v. 27, n. 11, p. 1467-1472, 1995. http://dx.doi.org/10.1016/00380717(95)00063-K

FERREIRA, A. S.; DE OLIVEIRA, R. S.; DOS SANTOS, M. A.; BORGES, E. N. Atividade respiratória da microbiota e conteúdo de glicose em resposta à adição de fósforo em solo de cerrado. Revista Brasileira de Ciência do Solo, v. 32, p. 1891-1897, 2008.

HANSON, P. J.; EDWARDS, N. T.; GARTEN, C. T.; ANDREWS, J. A. Separating root and soil microbial contributions to soil respiration: A review of methods and observations. Biogeochemistry, v. 48, p 115-146, 2000. http://dx.doi.org/10.1023/A:1006244819642

INSTITUTO BRASILEIRO DE GEOGRAFIA E ESTATÍSTICA - IBGE. Censo Agropecuário 2006. 2006. Available at: http://www.ibge.gov.br/home/estatistica/ economia/agropecuaria/censoagro/2006/defaulttab_censoagro.shtm. Accessed October 2015 .

INSTITUTO BRASILEIRO DE GEOGRAFIA E ESTATÍSTICA - IBGE. Levantamento Sistemático da Produção Agrícola-LSPA/2003 a 2009. 2010. Available at: http://www.ibge.gov.br/home/estatistica/indicadores/agropecuaria/lspa/.

Accessed October 2015. 
INSAM, H. Are the soil microbial biomass and basal respiration governed by the climatic regime? Soil Biology \& Biochemistry, v. 22, n. 4, p. 525-532, 1990. http://dx.doi.org/10.1016/0038-0717(90)90189-7

JESUS, E. C.; MARSH, T. L.; TIEDJE, J. M.; MOREIRA, F. M. S. Changes in land use alter the structure of bacterial communities in Western Amazon soils. ISME Journal, v. 3, p. 1004-1011, 2009. http://dx.doi.org/10.1038/ismej.2009.47

LUIZAO, R. C. C.; BONDE, T. A.; ROSSWALL, T. Seasonal variation of soil microbial biomass - the effects of clearfelling a tropical rainforest and establishment of pasture in the central amazon. Soil Biology and Biochemistry, v. 24, n. 8, p. 805-813, 1992. http://dx.doi.org/10.1016/0038-0717(92)90256-W

MARSCHNER, P.; MARINO, W.; LIEBEREI, R. Seasonal effects on microorganisms in the rhizosphere of two tropical plants in a polyculture agroforestry system in Central Amazonia, Brazil. Biology Fertility of Soils, v. 35, p. 68-71, 2002. http://dx.doi.org/10.1007/s00374-001-0435-3

MATSUOKA, M.; MENDES, I. C.; LOUREIRO, M. F. Biomassa microbiana e atividade enzimática em solos sob vegetação nativa e sistemas agrícolas anuais e perenes na região de primavera do leste (MT). Revista Brasileira de Ciência do Solo, v. 27, p. 425-433, 2003.

MENYAILO, O. V.; LEHMANN, J.; SILVA M. C.; ZECH, W. Soil microbial activities in tree-based cropping systems and natural forests of the Central Amazon, Brazil. Biology Fertility of Soils, v. 38, p. 1-9, 2003. http://dx.doi.org/10.1007/s00374-003-0631-4

MOREIRA, A.; COSTA, D. G. Dinâmica da matéria orgânica na recuperação de clareiras da floresta amazônica. Pesquisa Agropecuária Brasileira, v. 39, n. 10, p. 1013-1019, 2004.

MOREIRA, A.; MALAVOLTA, E. Dinâmica da matéria orgânica e da biomassa microbiana em solo submetido a diferentes sistemas de manejo na Amazônia Ocidental. Pesquisa Agropecuária Brasileira, v. 39, n. 11, p. 1103-1110, 2004.

MORTON, D. C.; DEFRIES, R. S.; SHIMABUKURO,Y. E.; ANDERSON, L. O.; ARAI, E.; ESPIRITO-SANTO, F. D. B. et al. Cropland expansion changes deforestation dynamics in the southern Brazilian Amazon. Proceedings of the National Academy of Sciences, v. 103, n. 39, p. 14637-14641, 2006. http://dx.doi.org/10.1073/pnas.0606377103

MUELLER, R. C.; PAULA, F. S.; MIRZA, B. S.; RODRIGUES, J. L. M.; NUSSLEIN, K.; BOHANNAN, B. J. M. Links between plant and fungal communities across a deforestation chronosequence in the Amazon rainforest. The ISME Journal, v. 8, p. 1548-1550, 2014. http://dx.doi.org/10.1038/ismej.2013.253

NEPSTAD, D. C.; STICKLER, C. M.; ALMEIDA, O. T. Globalization of the Amazon Soy and Beef Industries: Opportunities for Conservation. Conservation Biology, v. 20, p. 1595-1603, 2006. http://dx.doi.org/10.1111/j.1523-1739.2006.00510.x

NEPSTAD, D. C.; STICKLER, C. M.; SOARES, B; MERRY, F. Interactions among Amazon land use, forests and climate: prospects for a near-term forest tipping point. Philosophical Transactions of the Royal Society B-Biological Sciences, v. 363, p. 581 1737-1746, 2008. http://dx.doi.org/10.1098/rstb.2007.0036 
PARROTTA, J. A.; FRANCIS, J. K.; ROLO DE ALMEIDA, R. Trees of the Tapajos: a photographic field guide. Rio Piedras: United States Department of Agriculture Forest Service; International Institute of Tropical Forestry, 1995.

RODRIGUES, J. L. M.; PELLIZARI, V. H.; MUELLER, R.; BAEK, K.; JESUS, E. C.; PAULA, F. et al. Conversion of the Amazon rainforest to agriculture results in biotic homogenization of soil bacterial communities. Proceedings of the National Academy of Sciences, v. 110, p. 988-993, 2013. http://dx.doi.org/10.1073/pnas.1220608110

SALIMON, C. I.; DAVIDSON, E. A.; VICTORIA, R. L.; MELO, A. W. F. $\mathrm{CO}_{2}$ flux from soil in pastures and forests in southwestern Amazonia. Global Change Biology, v. 10, p. 833-843, 2004. http://dx.doi.org/10.1111/j.1529-8817.2003.00776.x

SILVER, W. L.; THOMPSON, A. W.; MCGRODDY, M. E.; VARNER, R. K.; DIAS, J. D.; SILVA, H. et al. Fine root dynamics and trace gas fluxes in two lowland tropical forest soils. Global Change Biology, v. 11, p. 290-306, 2005.

http://dx.doi.org/10.1111/j.1365-2486.2005.00903.x/abstract

SOKAL, R. R.; ROHLF, F. J. Biometry. 2. ed. New York: McGraw-Hill, 1981. 859 p.

VANCE, E. D.; BROOKES, P. C.; JENKINSON, D. S. An extraction method for measuring soil microbial biomass C. Soil Biology \& Biochemistry, v. 19, n. 6, p. 703-707, 1987. http://dx.doi.org/10.1016/0038-0717(87)90052-6

VERA-DIAZ, M. C.; KAUFMANN, R. K.; NEPSTAD, D. C.; SCHLESINGER, P. An interdisciplinary model of soybean yield in the Amazon Basin: the climatic, edaphic, and economic determinants. Ecological Economics, v. 65, p. 420-431, 2007. http://dx.doi.org/10.1016/j.ecolecon.2007.07.015

WARDLE, D.A.; GHANI, A. A critique of the microbial metabolic quotient (qc02) as a bioindicator of disturbance and ecosystem development. Soil Biol. Biochemistry, v. 27, n. 12, p. 1601-1610, 1995. http://dx.doi.org/10.1016/0038-0717(95)00093-T 